\title{
Response of a marine shallow-water sediment system to an increased load of inorganic nutrients
}

\author{
Per Nilsson ${ }^{1, *}$, Benno Jönsson ${ }^{2, *}$, Inger Lindström Swanberg ${ }^{2}$, Kristina Sundbäck $^{2}$ \\ ${ }^{1}$ Department of Zoology, University of Göteborg, PO Box 25059, S-400 31 Göteborg, Sweden \\ ${ }^{2}$ Department of Marine Botany, University of Göteborg, Carl Skottsbergs Gata 22, S-413 19 Göteborg, Sweden
}

\begin{abstract}
An outdoor experimental system was used to investigate the effect of an increased load of inorganic nitrogen and phosphorus on the lower trophic levels of the food web of a shallow-water sandy sediment. Estimates of structural changes were based on relationships between the biomass of autotrophs, heterotrophic bacteria and meiofauna and their qualitative composition. Effects on the functions of the sediment community were assessed by measuring primary and bacterial productivity and meiofaunal grazing rates using radiolabelling, as well as by measuring changes in oxygen and nutrient fluxes and carbon pools. The sediment system responded within 2 to $3 \mathrm{wk}$ to the nutrient enrichment. Meiofauna biomass increased, resulting in higher relative importance of oligochaetes and harpacticoid copepods. Primary productivity increased faster than meiofaunal grazing, resulting in an increase of microalgal biomass by a factor of 4 . Diatoms and filamentous cyanobacteria were favoured by the increased nutrient levels. The stimulated photosynthetic activity had a negative feedback on the producing sediment layer, which was lifted off by oxygen bubbles entrapped in the mucus-rich top most layer. Stimulated growth of the filamentous green alga Enteromorpha clathrata resulted in a biomass of ca $2 \mathrm{~g} \mathrm{C} \mathrm{m}^{-2}$ after $4 \mathrm{wk}$, which was more than 2 times the biomass of microautotrophs living in the sediment. Bacterial productivity responded only weakly to the nutrient additions and the grazing pressure on bacteria was high during the whole 4 wk experiment. Meiofauna removed on average about $4 \%$ of the microalgal biomass and $12 \%$ of the bacterial biomass per day in treatments with increased nutrient levels, and about $10 \%$ of autotrophs and $7 \%$ of bacteria in treatments with ambient nutrient levels. Although autotrophic organisms were more important carbon sources than bacteria for meiofauna, the impact of grazing on microautotrophs was small, whereas grazing may be important in regulating bacterial growth. Measurements of ammonium, nitrate, phosphate and silicate flux showed that shallow-water sediment with a high primary productivity in the top layer functions as a sink for inorganic nutrients. In terms of biomass, the addition of nutrients led to a dominance of meiofauna. However in terms of productivity, autotrophs predominated and thus, during the initial phase of increasing nutrient levels, the entire sediment system was dominated by autotrophic processes.
\end{abstract}

\section{INTRODUCTION}

During the last decade, eutrophication of Scandinavian coastal waters has attracted attention because of increased algal blooms and subsequent anoxia of bottom waters. Several investigations have concentrated on the processes in the plankton community and the consequences for the benthic macrofauna (for references see Rosenberg et al. 1990). For the Kattegat and Skagerrak area, efforts have also been made to identify the most limiting nutrient for pelagic primary production (Granéli et al. 1990) as well as the main sources of the increased nutrient load (Rosenberg et al.

\footnotetext{
- Present address: Tjärnö Marine Biological Laboratory, Pl.
} 2781, S-452 00 Strömstad, Sweden
1990). In the long term, a changed nutrient status may lead to a fundamental change in the structure and functioning of food webs, and the question has been raised whether eutrophication is currently changing the basis of the pelagial food web from a diatom-based system towards a system based on flagellates, a less desirable food source (Doering et al. 1989 and references therein).

Since many commercially important fish species and other macrofauna depend on shallow-water sediment areas as nursery and foraging grounds (Pihl 1989), it is essential to include these areas in research on maninduced changes. Many such areas occur along the Swedish coastline. There is still a lack of basic knowledge about the interaction between primary producers and consumers in shallow-water benthic communities, 
especially in non-tidal sediment systems. Even less is known about the response of such communities to an increased load of nutrients.

The aim of our investigation was to study the effect of increased loads of inorganic nitrogen and phosphorus in the water column on the lower trophic levels of the food web of a shallow-water sandy sediment, by using an outdoor experimental set-up. In particular, we studied the impact of elevated nutrient concentrations on the pathways of carbon between producers and consumers by measuring meiofaunal grazing rates and grazing pressure on autotrophs and bacteria. Primary and bacterial productivity, changes in carbon and nitrogen pools, and inorganic nutrient fluxes were also measured as indicators of functional parameters. Estimates of structural changes were based on relationships between the biomass and qualitative composition of autotrophs, meiofauna, and heterotrophic bacteria.

\section{MATERIAL AND METHODS}

Experimental set-up. The experiment was run at Tjärnö Marine Biological Laboratory on the west coast of Sweden $\left(58^{\circ} 52^{\prime} \mathrm{N}, 11^{\circ} 09^{\prime} \mathrm{E}\right)$, using an outdoor flowthrough system consisting of eight $30 \mathrm{l}$ containers placed in a floating frame. A detailed description of the experimental set-up, including an illustration, is given in Sundbäck et al. (1990). Sandy sediment was collected from a nearby shallow bay ( $0.2 \mathrm{~m}$ water depth) in 2 layers (the top $1 \mathrm{~cm}$ was kept separate) and sieved (mesh size $0.5 \mathrm{~mm}$ ) to remove macrofauna. The sand was homogenized and spread out in 2 layers $(2 \mathrm{~cm}$ of surface sediment on top of a $8 \mathrm{~cm}$ thick bottom layer) in each experimental container (area $0.1 \mathrm{~m}^{2}$ ). The separated collection of surface and deep sediment was done to ensure a more natural biotic assemblage in the containers, since animals, autotrophs and bacteria in general show a clear vertical gradient with more organisms at or near the sediment surface. Seawater from 2 $m$ depth was filtered through 2 cotton-filter cartridges (50 $\mu \mathrm{m}$ and $1 \mu \mathrm{m}$; Vattenteknik, Malmö) into 2 immersed $100 \mathrm{l}$ cisterns. From these cisterns water was pumped through the experimental containers using a multichannel peristaltic pump at a flow-rate of $1.6 \mathrm{l} \mathrm{h}^{-1}$, corresponding to a turnover time of $12 \mathrm{~h}$. The water entered the experimental containers $1 \mathrm{~cm}$ above the sediment surface and the height of the water column above the sediment was $18 \mathrm{~cm}$. The system was run with filtered seawater for $10 \mathrm{~d}$ prior to the start of nutrient addition, in order to allow the sediment to stabilize.

From the third day of the experiment and onwards the water in 1 of the 2 cisterns was enriched with $\mathrm{NaNO}_{3}$ and $\mathrm{K}_{2} \mathrm{HPO}_{4}$ to a final concentration of ca 85 $\mu \mathrm{mol} \mathrm{l}^{-1}$ inorganic nitrogen (IN) and $2.5 \mu \mathrm{mol} \mathrm{l}^{-1}$ inorganic phosphorus (IP), simulating nutrient levels and $N / P$ ratios found in shallow coastal areas influenced by river or sewage-plant effluents (Granéli \& Sundbäck 1985, Fleischer et al. 1987). Four containers received this enriched water, corresponding to a mean nutrient input of $27.5 \mathrm{mmol} \mathrm{IN}$ and $0.74 \mathrm{mmol} I P \mathrm{~m}^{-2} \mathrm{~d}^{-1}$. Four other containers receiving non-enriched water from the other cistern served as controls. The experiment was run for 4 wk (12 August to 9 September 1988). The inner walls of the containers were kept clean from algal growth (benthic autotrophs migrating from the sediment) by carefully wiping the surfaces every 3 to $4 \mathrm{~d}$ with clean cloths rinsed in distilled water.

Sampling and analyses. At each sampling one core (transparent PVC tube, i.d. $67.8 \mathrm{~mm}$ ) was taken from each container. These cores were constructed to ensure homogenous isotope labelling of the undisturbed sediment by allowing labelled water to slowly percolate into the topmost $10 \mathrm{~mm}$ of the sediment (Jönsson in press; see also section on radiotracer measurements in this study). An additional core was taken from one enriched and one control container to measure dark fixation of ${ }^{14} \mathrm{C}$ and to be used as background controls in grazing measurements (see below 'Radiotracer measurements'). The holes in the sediment surface caused by the core-sampling were filled with autoclaved sediment to minimize leakage of sulfide and other solutes from the anoxic layers. Samples $(600 \mathrm{ml})$ from the cisterns and from the overlying water of each container were taken for analyses of inorganic nutrients $\left(\mathrm{NH}_{4}^{+}\right.$. $\mathrm{NO}_{3}^{-}+\mathrm{NO}_{2}^{-}, \mathrm{PO}_{4}^{3-}$ and $\left.\mathrm{Si}(\mathrm{OH})_{4}\right)$ on the day before radiotracer incubations. Samples were taken once a week, altogether on 5 occasions. Sediment samples for content of particulate organic carbon and nitrogen were taken at the start and at the end of the experiment.

After the termination of the incubations (see 'Radiotracer measurements'), subsamples were taken from each of the 10 cores using cut-off plastic syringes (13 subsamples in total): 1 core (i.d. $22 \mathrm{~mm}$ ) for meiofauna and 2 cores (i.d. $9 \mathrm{~mm}$ ) for analysis of the number of living autotrophic microflora, bacterial counts, chlorophyll a content, primary productivity $\left({ }^{14} \mathrm{C}\right.$ uptake), bacterial production ( ${ }^{3} \mathrm{H}$-thymidine incorporation into bacterial DNA) and labelling of bacteria as food source $\left({ }^{3} \mathrm{H}\right.$-thymidine incorporation into cells). Thus samples for all variables, structural as well as functional, were taken from the same incubation core. The top $5 \mathrm{~mm}$ of the sediment was used for analyses.

Benthic microalgal cells. Two subsamples from each incubation core were pooled, diluted to $6 \mathrm{ml}$ and treated in a sonication bath for $9 \min (35 \mathrm{kHz})$. Living autotrophic cells were counted using epifluorescence microscopy as described in Sundbäck et al. (1990). 
Cells were grouped into size and shape classes, and then identified when possible to genus level. In addition, the average cell volume and carbon content for each group were calculated. The factor to convert cell volume to biomass values expressed as carbon varied between 0.085 and 0.11 (see Sundbäck et al. 1990).

Filamentous macroalgae. At the end of the experiment the filamentous macroalgae growing in the enriched containers were harvested by hand, dried $\left(40^{\circ} \mathrm{C}\right)$ to assess dry weight and then analysed for organic carbon and nitrogen content (see POC section below).

Meiofauna. Meiofauna samples preserved in $4 \%$ borax-buffered formalin were extracted, sieved, sorted and counted as described in Sundbäck et al. (1990) and ash-free dry weight (AFDW) was converted to carbon using a factor of 0.45 (Båmstedt 1986). To measure incorporation of ${ }^{3} \mathrm{H}$ and ${ }^{14} \mathrm{C}$ via grazing, the samples were counted in a scintillation counter (LKB-Wallac 1217) within $24 \mathrm{~h}$.

Bacteria. The number of bacteria was counted using acridine orange epifluorescence microscopy as previously described in Sundbäck et al. (1990). Bacterial volume was converted to carbon using the conversion factors $A F D W=0.15 \times$ volume (Finlay \& Uhlig 1981) and carbon $=0.43 \times$ AFDW (Fenchel \& Finlay 1983) .

Particulate organic carbon (POC) and nitrogen (PON). The content of POC and PON of sediment and macroalgal samples were measured using a Heraeus CHN-O-RAPID elemental analyser. For POC analyses, the sediment samples were treated with $2.5 \mathrm{M} \mathrm{HCl}$ and dried overnight at $50^{\circ} \mathrm{C}$ to remove inorganic carbon.

\section{Radiotracer measurements.}

Incubation procedure: From each incubation core, excess overlying water was removed so that the water level was $20 \mathrm{~mm}$ above the sediment surface. Fifty $\mu \mathrm{Ci}$ of [methyl ${ }^{3} \mathrm{H}$ ]-thymidine (giving a final concentration of $7.6 \mathrm{nM}$ ) and $9 \mu \mathrm{Ci}$ of ${ }^{14} \mathrm{C}$-bicarbonate were added to each core. The water was gently stirred and then allowed to percolate ca $10 \mathrm{~mm}$ into the sediment. The speed of percolation was $10 \mathrm{~mm}$ in $2 \mathrm{~min}$. The core was then placed in an outdoor water bath cooled with flowing seawater. A transparent plastic lid was placed over each incubation tube to prevent evaporation and to screen off some of the sun, giving a light intensity similar to that under $20 \mathrm{~cm}$ of water column. The process of starting the incubations, from the sampling in the containers until the cores were placed in the water bath, took less than 10 min.

The thymidine incorporation for measuring bacterial productivity and grazing of bacteria was considered to start when the labelled water had percolated into the sediment. Incorporation of ${ }^{14} \mathrm{C}$ for primary productivity and estimation of grazing on microalgae was considered to start when the tubes were placed in the water- bath (during the addition of label the tubes were kept in dimmed light). After ca $2 \mathrm{~h}$ incubation the tubes were taken into the laboratory and samples were taken immediately as described above in 'Sampling and analyses'. The exact time for stopping the incorporation of label of each core was noted. In this way the cores were incubated for different times but all cores were incubated between 2 and $3 \mathrm{~h}$. This is longer that normally used for bacterial production studies, and the risk of isotope recirculation increases with time, but pilot studies indicated that grazers did not become substantially labelled until after ca $2 \mathrm{~h}$. However, pilot studies also suggested that uptake of tracer by food organisms was linear over this timespan.

Primary productivity: Sediment samples were transferred to scintillation vials, 5 drops of $0.1 \mathrm{M} \mathrm{HCl}$ were added and the samples were allowed to dry for $2 \mathrm{~h}$ at $40^{\circ} \mathrm{C}$. Samples were counted in a liquid scintillation counter as described below. Total carbon dioxide concentration in the water and carbon assimilation were calculated using equations in Ærtebjerg Nielsen \& Bresta (1984). All calculations were corrected for dark fixation and converted to daily production using insolation values obtained by a Kipp and Zonen solarimeter placed on the laboratory roof.

Incorporation of ${ }^{3} \mathrm{H}$-thymidine into bacteria: Sediment samples for measurement of thymidine incorporation were transferred to test tubes and incorporation was stopped by addition of $0.25 \mathrm{ml} 5 \mathrm{M} \mathrm{NaOH}$ and 0.25 $\mathrm{ml}$ of $1.65 \mathrm{mM}$ unlabeled thymidine. We used 2 different extraction methods to estimate the amount of radioactivity in bacteria: one method (1) to extract the labelled DNA for productivity measurements, and a second method (2) to measure the total amount of ${ }^{3} \mathrm{H}$ thymidine incorporated in bacterial cells available to grazers.

(1) DNA was extracted using the method described by Wicks \& Robarts (1987). In their study this method had an extraction efficiency of $75 \%$ of the DNA recovered. Since we did not test for recovery, we applied this efficiency to our production estimations. The dilution of ${ }^{3} \mathrm{H}$-thymidine by competing precursors internally in the bacterial cells as well as externally in the sediment was checked using the method of Pollard \& Moriarty (1984), in which unlabeled thymidine is added in a series of increasing concentrations to a sediment containing a fixed amount of labelled thymidine. We found a degree of participation of the labelled thymidine of $30 \%$, and a specific activity of the ${ }^{3} \mathrm{H}$-thymidine of $26.3 \mathrm{Ci} \mathrm{mmol}^{-1}$. Incorporation of isotope was converted to bacterial production according to Moriarty \& Pollard (1981) but assuming a conversion factor of $2 \times 10^{18}$ cells produced per incorporated mole thymidine (Pollard \& Moriarty 1984).

(2) To estimate the total amount of label in bacteria 
available to grazers, the uptake of ${ }^{3} \mathrm{H}$ was stopped in the same way as for the 'productivity samples', i.e. by adding $\mathrm{NaOH}$ and surplus unlabeled thymidine. The samples were then rinsed several times on $0.2 \mu \mathrm{m}$ nitrate-cellulose filters using sterile seawater, thereby washing away unincorporated ${ }^{3} \mathrm{H}$-thymidine and retaining the label incorporated into the bacterial cells on the filter. This fraction constituted the component available to meiofaunal grazers.

Measurements of meiofaunal grazing rates: Grazing on bacteria and microalgae by meiofauna was estimated by the in situ dual-labelling technique originally suggested by Daro (1978) and further developed by Montagna (1984) and Montagna \& Bauer (1988): Tracer is added to a water sample or sediment core containing food organisms (bacteria and/or microalgae) and grazers, and the core is incubated for a short period (minutes to a few hours). The incubation is then stopped, the organisms extracted and the radioactivity in food organisms and grazers is measured. The grazing rate $(G)$ equals $2 M / B t$, where $M=$ radioactivity in grazers, $B=$ radioactivity in food organisms and $t=$ incubation time (Daro 1978). For this to be valid, the uptake of label must be linear with time (i.e. the available label is not exhausted during the incubation), the amount of tracer in food must be greater than the amount of label in grazers during the experiment and the tracer should not be recirculated by the grazers (see Daro 1978 and Montagna 1984 for details). Dark cores to which nalidixic acid $\left(400 \mu \mathrm{g}^{-1}\right)$ and 5 deoxythymidine $\left(4 \mu \mathrm{g} \mathrm{l}^{-1}\right)$ were added as inhibitors of ${ }^{3} \mathrm{H}$-incorporation into DNA were used as background controls in grazing measurements (Montagna \& Bauer 1988).

All samples for scintillation (primary productivity, bacterial productivity and grazing) were dissolved in 1 ml Soluene ${ }^{\circledR}-350$ (Packard) for $8 \mathrm{~h}$ and $15 \mathrm{ml}$ Hionicfluor $^{\mathrm{TM}}$ (Packard) were added. The samples were counted in a liquid scintillation counter (LKB-Wallac 1217) using a dual-label window setting.

Oxygen. The oxygen concentrations of the inflowing water (= the water in the 2 cisterns) and in the unstirred overlying water of the experimental containers were measured with a YSI Model 58 oxygen electrode. During the measurements, the electrode was kept 1 to $2 \mathrm{~cm}$ above the sediment surface.

Inorganic nutrients. Samples for analyses of $\mathrm{NH}_{4}^{+}$, $\mathrm{NO}_{3}^{-}+\mathrm{NO}_{2}^{-}, \mathrm{PO}_{4}^{3-}$ and $\mathrm{Si}(\mathrm{OH})_{4}$ were taken from the cisterns and, after stirring, from the overlying water of each experimental container. The samples were immediately filtered (Whatman GF/F, retention capacity $0.7 \mu \mathrm{m})$ and nutrients were analysed according to methods described by Carlberg (1972).

Statistical analyses. Homogeneity of variances was tested with a variance ratio test. If variances were heterogeneous, the samples were tested with Taylor's power law (Green 1979) and transformed to $\ln (x+1)$ or $(x+1)$ where necessary. Differences between dates and treatments were tested using 2-way ANOVA. Inspection of residual plots suggested that transformations were successful in reducing non-normality and heterogeneity of variances. Pairways testing of means was done with Student-Newman-Keuls multiple comparison test (SNK).

\section{RESULTS}

\section{Visual observations}

On the 4th day after the start of the treatment, the sediment surface in the enriched containers was more brownish in colour than in the control containers. In all 8 containers, bubbles of oxygen on the sediment surface rose to the water surface. Towards the end of the experiment, flakes of the sediment surface were lifted off in the enriched containers by rising oxygen bubbles. On Day 12, the first tufts of the filamentous green alga Enteromorpha clathrata (Roth) Greville were observed on the sediment in the enriched containers and by Day 28 , the filaments started to float up to the water surface.

\section{Autotrophic microflora}

Microbenthic primary productivity in the sediment was significantly stimulated by the nutrient addition (ANOVA, $\mathrm{p}<0$ 001) and after 3 wk was 4 times (mean $686 \mathrm{mg} \mathrm{C} \mathrm{m}^{-2} \mathrm{~d}^{-1}$ ) the primary productivity in the control containers (Fig. 1). However, at the end of the experiment the values in the enriched containers (mean $253 \mathrm{mg} \mathrm{C} \mathrm{m}^{-2}$ day $^{-1}$ ) had dropped to almost the same level as in the control containers. The chlorophyll $a$ values showed the same pattern (Fig. 2). In the enriched containers, the chlorophyll content increased from a mean value of $75 \mathrm{mg} \mathrm{m}^{-2}$ on Day 7 to $153 \mathrm{mg}$ $\mathrm{m}^{-2}$ on Day 21, and on Days 14 and 21 there were

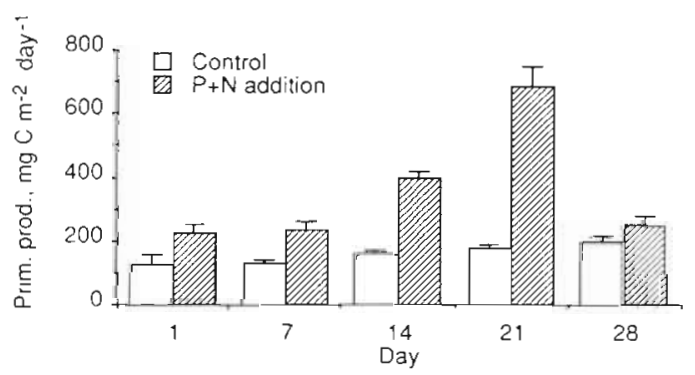

Fig. 1. Microbenthic prmary productivity in the top $5 \mathrm{~mm}$ sediment in containers without (control) and with addition of inorganic phosphorus (2.5 $\mathrm{mPO}_{4}^{3-}$ ) and nitrogen (85 um $\mathrm{NO}_{3}^{-}$) to the overlying water. Bars show means of 4 replicate containers $+S E$ 


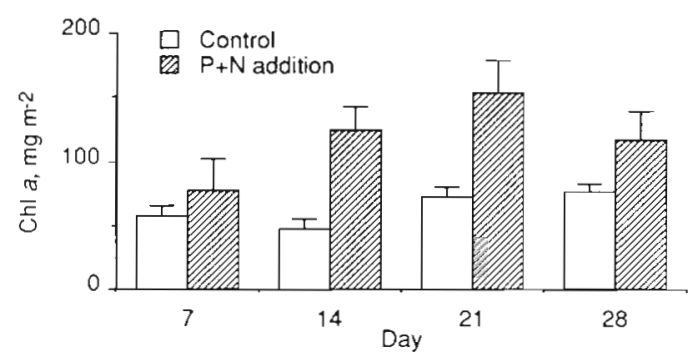

Fig. 2. Chlorophyll a content in the top $5 \mathrm{~mm}$ sediment. Bars show mean $+\mathrm{SE}$ of 4 replicate containers. For explanation of treatments see Fig. 1

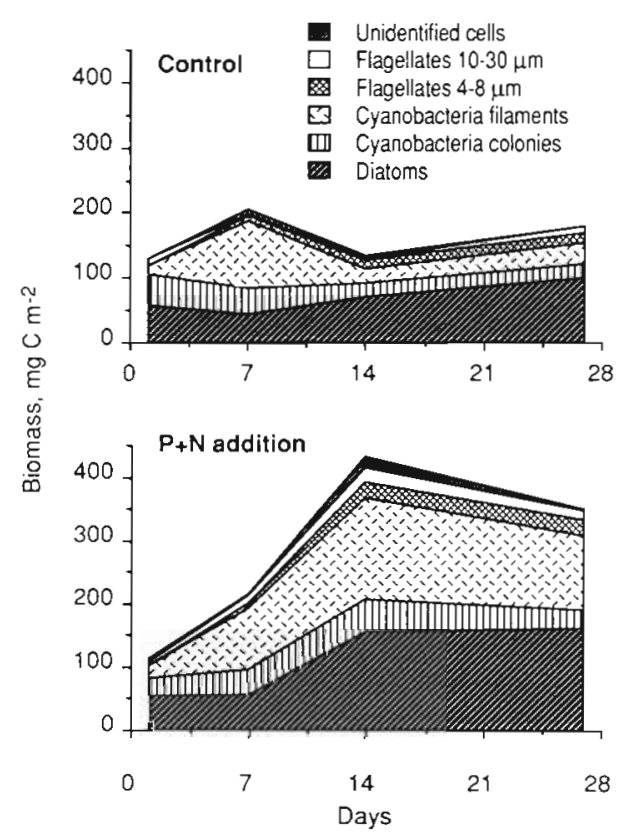

Fig. 3. Biomass and composition of autotrophic benthic microflora in the top $5 \mathrm{~mm}$ sediment. Curves are based on means of 4 replicate containers. For explanation of treatments see Fig. 1

significant differences between the treatments (SNK, $\mathrm{p}<0.05)$. On the last day, the chlorophyll values of enriched containers declined to a level not significantly different from those of control containers.

Initially the diatoms accounted for $47 \%$ (mean value for all containers), the cyanobacteria for $46 \%$, and various flagellates for $7 \%$ of the total biomass of living autotrophic microalgae (Fig. 3). During the first week of the experiment the biomass increased in all containers due to the growth of filamentous cyanobacteria (Fig. 3). Later, their biomass decreased in the control containers and consequently the proportion of diatoms increased. In the $\mathrm{P}+\mathrm{N}$ enriched containers, the microalgal biomass increased significantly (SNK, $p<0.05$ ) from 113 to $455 \mathrm{mg} \mathrm{C} \mathrm{m}^{-2}$ and at the end of the experiment, despite a declining trend, was twice as high as in the controls (350 and $180 \mathrm{mg} \mathrm{C} \mathrm{m}^{-2}$, respectively). The biomass increase was mainly accounted for by both filamentous cyanophytes (Oscillatoria spp.) and small-sized diatoms, and thus the ratio between these 2 algal groups remained unchanged. In addition, the proportion of flagellate biomass, in particular those within the size range 4 to $8 \mu \mathrm{m}$, increased significantly (SNK, $\mathrm{p}<0.05$ ) in enriched containers, even though they comprised at most only $15 \%$ of the total living microalgal biomass. For a detailed analysis of the microalgal composition, and in particular diatoms, see Sundbäck \& Snoeijs (in press).

\section{Filamentous macroalgae}

At the end of the experiment, the Enteromorpha clathrata tufts in the nutrient-enriched containers were 15 to $20 \mathrm{~cm}$ long with a mean biomass $(14.8 \mathrm{~g}$ dry weight per $\mathrm{m}^{2}$ ) corresponding to $2.2 \mathrm{~g} \mathrm{C}$ and $0.19 \mathrm{~g} \mathrm{~N}$ $\mathrm{m}^{-2}$. No growth of E. clathrata was observed in the control containers.

\section{Meiofauna}

The meiofauna was stimulated by the addition of nutrients. The biomass increased in both treatments during the experiment (a significant difference between days; ANOVA, $p<0.001$ ), but the increase was greater in the enriched containers (from 83 to 802 $\mathrm{mg} \mathrm{C} \mathrm{m}^{-2}$ ) than in control containers (from 83 to $441 \mathrm{mg}$ $\mathrm{C} \mathrm{m}^{-2}$ ), resulting in a significant difference in biomass
Fig. 4. Biomass and composition of meiofauna in the top $5 \mathrm{~mm}$ sediment. Curves are based on means of 4 replicate containers. For explanation of treatments see Fig. 1
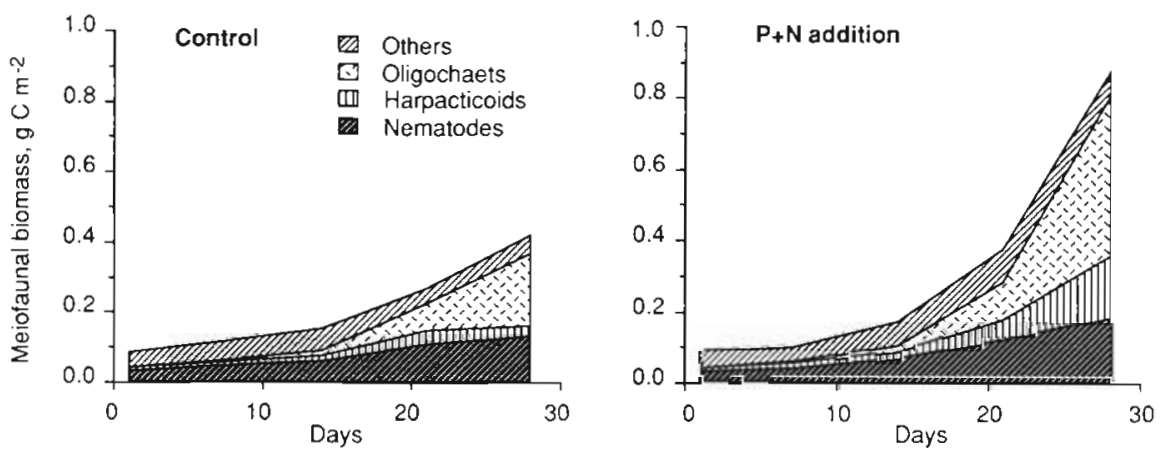


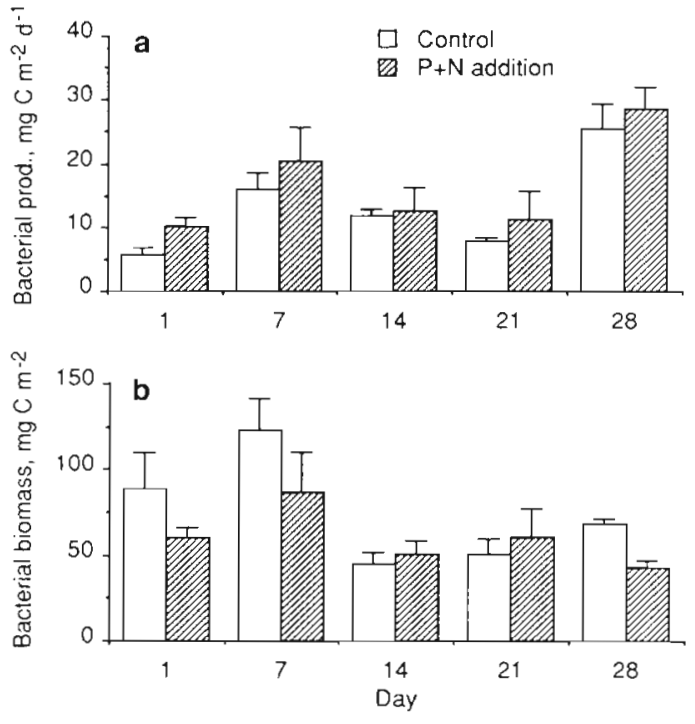

Fig. 5. (a) Gross bacterial productivity and (b) biomass in the top $5 \mathrm{~mm}$ sediment. Each bar shows mean $+\mathrm{SE}$ of 4 replicate containers. For explanation of treatments see Fig. 1

on Day 28 ( $S N K, p<0.05)$. A large part of the biomass increase was due to oligochaetes, which on Day 28 constituted $50 \%$ of the biomass in nutrient-enriched containers and $33 \%$ in control containers. Harpacticoid copepods also seemed to benefit from the addition of nutrients.

\section{Bacterial productivity and biomass}

The bacterial productivity did not respond significantly to the nutrient addition (Fig. 5a). Even though the productivity was slightly higher in $\mathrm{P}+\mathrm{N}$ enriched containers than in control containers, this difference was not statistically significant (ANOVA, $p=0.14$ ). However, there was a great difference between days (ANOVA, $\mathrm{p}<0.001$ ). Small differences between treatments were also found in bacterial biomass (Fig. 5b), where there was a significant difference between days (ANOVA, $p<0.001$ ) but not between treatments (ANOVA, $p=0.175$ ). The biomass ( 40 to $130 \mathrm{mg} \mathrm{C} \mathrm{m}^{-2}$ ) and productivity values ( 6 to $29 \mathrm{mg} \mathrm{C} \mathrm{m}^{-2} \mathrm{~d}^{-1}$ ) suggest a doubling time of ca 32 to $310 \mathrm{~h}$.

\section{Organism groups}

At the start of the experiment the total carbon accounted for by meiofauna, bacteria and viable autotrophic flora was 260 to $300 \mathrm{mg} \mathrm{m}^{-2}$. This value increased during the $4 \mathrm{wk}$ experiment to $764 \mathrm{mg} \mathrm{C} \mathrm{m}^{-2}$ in the control containers and to $1265 \mathrm{mg} \mathrm{C} \mathrm{m}^{-2}$ in the enriched containers (Fig. 6). Initially the biomass of autotrophic microalgae dominated (43 to $44 \%$ ) over bacterial and meiofaunal carbon (each within the range 23 to $33 \%$ ), but at the end of the experiment the biomass was dominated by meiofauna in both treatments, and accounted for ca $2 / 3$ of the living carbon.

\section{POC and PON}

The mean POC content of the sediment at the start of the experiment was $11.7 \mathrm{~g} \mathrm{C} \mathrm{m}^{-2}$ (Fig. 7a). On the last sampling date, the POC content had increased in all but one container by values varying between 0.9 and $11.4 \mathrm{~g} \mathrm{C} \mathrm{m}^{-2}$. The mean increase for control containers was 5.1 and $5.9 \mathrm{~g} \mathrm{~m}^{-2}$ for the enriched containers. There was a significant difference between days in both treatments (ANOVA, $p<0.01$ ); however, because of the large variation there was no significant difference between treatments (ANOVA, $p>0.1$ ). PON values increased significantly (ANOVA, $p<0.01$ ) from the initial mean value of $1.96 \mathrm{~g}$ by 0.8 to $0.9 \mathrm{~g} \mathrm{~N} \mathrm{~m}^{-2}$ (Fig. $7 b)$. The initial mean $\mathrm{C} / \mathrm{N}$ mole ratio of 7 did not change significantly for either time or treatment.

\section{Meiofaunal grazing rates}

Grazing rates were generally between 2.5 and $15 \%$ of both autotrophs and bacteria (expressed as a fraction of biomass removed per day), the one exception being a very high grazing of $40 \%$ on bacteria in enriched
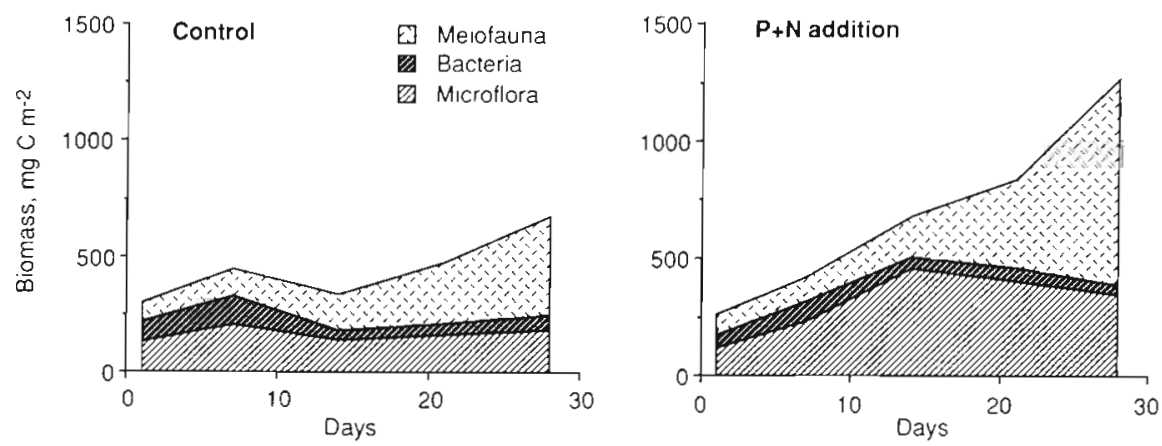

Fig. 6. Biomass and proportions between groups of organism in the top 5 $\mathrm{mm}$ sediment. Curves are based on means of 4 replicate containers. For explanation of treatments see Fig. 1 

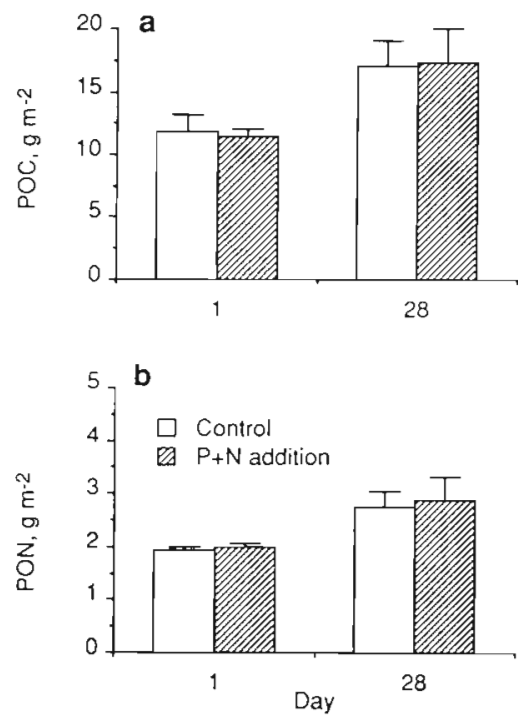

Fig. 7. (a) POC and (b) PON content in the top $5 \mathrm{~mm}$ sediment at the start and in the end of the experiment. Each bar shows mean $+\mathrm{SE}$ of 4 replicate containers. For explanation of treatments see Fig. 1

containers on Day 21 (Figs. $8 \& 9$ ). Meiofauna removed on an average about $10 \%$ of the microalgal biomass and $7 \%$ of the bacterial biomass per day in containers with ambient nutrient levels, and about $4 \%$ autotrophs and $12 \%$ bacteria in enriched containers. Variances were high however, and differences between treatments were not statistically significant (ANOVA, $p>0.2$ ). Meiofaunal grazing rates on autotrophs were generally higher in control containers (up to $13 \%$ of autotrophic biomass grazed per $24 \mathrm{~h}$ ) than in nutrientenriched containers (up to $5.5 \%$ biomass grazed) (Fig. 8). Since the autotrophic biomass was higher in $\mathrm{P}+\mathrm{N}$ enriched containers than in control containers, the actual amount of autotrophic carbon ingested during the experimental period was higher in the enriched containers (ca $490 \mathrm{mg} \mathrm{C} \mathrm{m}^{-2}$ ) than in control containers (ca $360 \mathrm{mg} \mathrm{C} \mathrm{m}^{-2}$ ). Grazing rates increased towards the end of the experiment, probably due to the increased meiofaunal biomass (cf. Fig. 4). Grazing rates on bacteria (Fig. 9) were similar to the grazing on autotrophic algae, but since the biomass of autotrophs was on an average 4 times the biomass of bacteria, the ingestion of autotrophic carbon was higher than the ingestion of bacterial carbon.

When the whole period is considered, the grazing by nematodes and by the group 'Others' (which includes the oligochaetes) was about $40 \%$ each of total grazing, while harpacticoids accounted for 10 to $20 \%$ of the total grazing. Towards the end of the experiment (Days 21 and 28) the harpacticoids' share of the grazing in the $\mathrm{P}+\mathrm{N}$ enriched containers increased to between 30 to 35 $\%$. About 60 to $90 \%$ of the carbon that nematodes and 'Others' grazed were autotrophic carbon, and this fraction tended to increase with time in both treatments. Harpacticoids grazed about equal amounts of bacterial and autotrophic carbon and this did not change much with time or treatments, though it is difficult to draw any firm conclusions due to the great variation of grazing estimates.

\section{Oxygen}

The oxygen level in the inflowing water varied between 2.6 and $7 \mathrm{mg} \mathrm{O}_{2} \mathrm{l}^{-1}$ and was never below 5 $\mathrm{mg} \mathrm{O}_{2} \mathrm{l}^{-1}$ in the overlying water in the experimental
Fig. 8. Fraction of autotrophic biomass grazed per day by meiofaunal groups. Each bar shows mean $+\mathrm{SE}$ of 4 replicate containers. For explanation of treatments see Fig. 1

Fig. 9. Fraction of bacterial biomass grazed per day by meiofaunal groups. Each bar shows mean +SE of 4 replicate containers. For explanation of treatments see Fig. 1
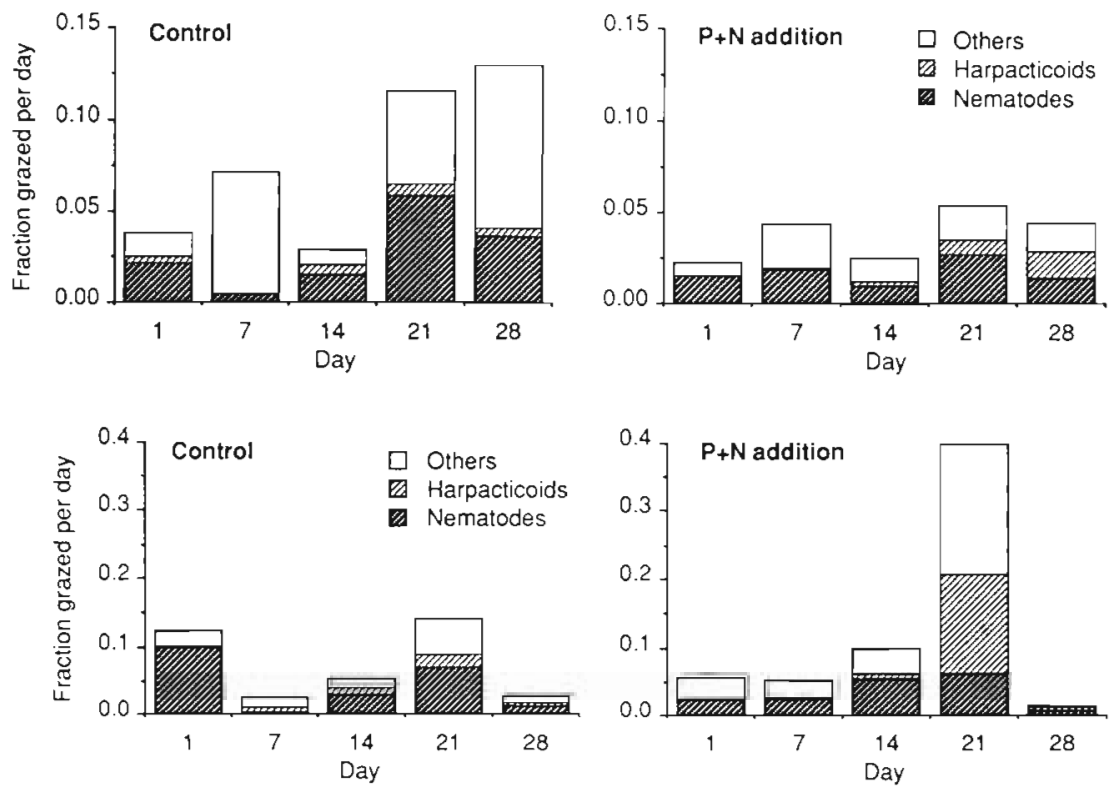


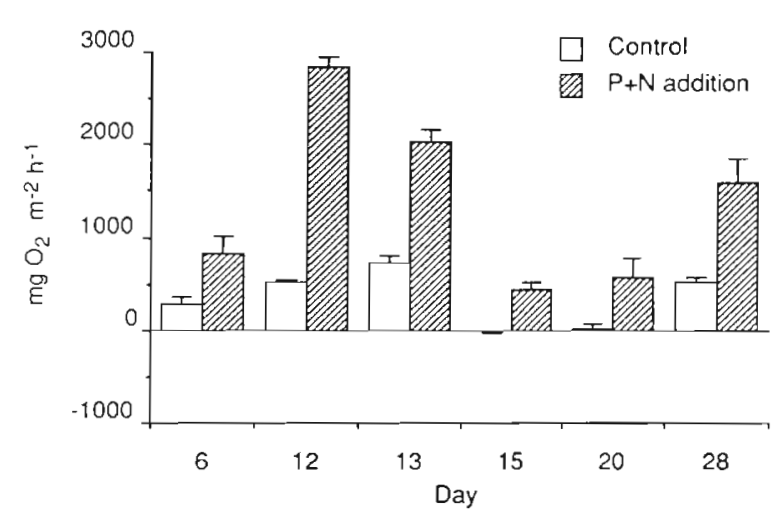

Fig. 10. Oxygen flux calculated from concentrations in the overlying water. Bars are based on means of 4 replicate containers +SE. For explanation of treatments see Fig. 1

containers. Calculation of oxygen flux showed that there was a nel oxygen production in all containers, and that the production was significantly higher (by factors 3 to 18) on all occasions (ANOVA, p <0.001) in enriched containers, mean values varying between 19 and $119 \mathrm{mg} \mathrm{O}_{2} \mathrm{~m}^{-2} \mathrm{~h}^{-1}$ (Fig. 10). Since oxygen was measured in the morning, thus representing rather low values (cf. Sundbäck et al. 1990), the positive net flux values indicated that no net oxygen consumption occurred during day-time. Sediment cores taken on the 5 incubation days showed a brown or green sediment layer several $\mathrm{mm}$ into the sediment, and black spots were never observed at the sediment surface. Therefore we do not think that it is likely that anoxic conditions developed on the sediment surface during the night.

\section{Inorganic nutrients}

As is usual in surface water in late summer, the concentration of inorganic nutrients in the influent water was generally low $\left(\mathrm{PO}_{4}^{3-}<0.2 \mu \mathrm{M}, \mathrm{NO}_{3}^{-}+\mathrm{NO}_{2}^{-}\right.$ $<1 \mu \mathrm{M}, \mathrm{NH}_{4}^{+}$varied between 0.35 and $8.5 \mu \mathrm{m}$ and $\mathrm{Si}(\mathrm{OH})_{4}$ between 2.5 and $\left.7.5 \mu \mathrm{M}\right)$. The fluxes of all these nutrients were dominated by uptake, i.e. a decrease of the concentration in the overlying water (Fig. 11).

In control containers, nitrogen was taken up mainly as $\mathrm{NH}_{4}^{+}$, whereas uptake of $\mathrm{NO}_{3}^{-}+\mathrm{NO}_{2}^{-}$was negligible in some cases while for others $\mathrm{NO}_{3}^{-}+\mathrm{NO}_{2}^{-}$was released (Fig. $11 \mathrm{a}$, b). Although $\mathrm{NH}_{4}^{+}$disappeared at a mean maximum rate of $1.8 \mathrm{mmol} \mathrm{m} \mathrm{m}^{-2} \mathrm{~d}^{-1}$ during the second week, it was released at the end of the experiment (60 $\mu \mathrm{mol} \mathrm{m} \mathrm{m}^{-2} \mathrm{~d}^{-1}$ ) (Fig. 11b). On the other hand, the uptake of $\mathrm{NH}_{4}^{+}$in the $\mathrm{NO}_{3}^{-}$-enriched containers was either significantly lower (10 to $\left.90 \mu \mathrm{mol} \mathrm{m} \mathrm{m}^{-2} \mathrm{~d}^{-1}\right)$ or there was a release of $\mathrm{NH}_{4}^{+}$(maximum rate $480 \mu \mathrm{mol}$ $\mathrm{m}^{-2} \mathrm{~d}^{-1}$ ) (Fig. 11b). The added $\mathrm{NO}_{3}^{-}$was taken up at a mean rate of between 5.7 and $13.3 \mathrm{mmol} \mathrm{m}^{-2} \mathrm{~d}^{-1}$, which corresponded to between 21 and $50 \%$ of the daily nitrate load (Fig. 11a).

The $\mathrm{PO}_{4}^{3-}$ flux was small in the control containers, varying between an uptake of $13 \mu \mathrm{mol} \mathrm{m} \mathrm{m}^{-2} \mathrm{~d}^{-1}$ and a release of $14 \mathrm{mmol} \mathrm{m}^{-2} \mathrm{day}^{-1}$ (Fig. 11c). In the enriched containers $\mathrm{PO}_{4}^{3-}$ was taken up by the sediment during the first $3 \mathrm{wk}$ at a mean rate of $410 \mu \mathrm{mol} \mathrm{m} \mathrm{m}^{-2} \mathrm{~d}^{-1}$, thus binding $55 \%$ of the daily phosphate load into the sediment (Fig. 11c). On the last day of the experiment the uptake had decreased to ca $20 \mu \mathrm{mol} \mathrm{m} \mathrm{m}^{-2} \mathrm{~d}^{-1}$.

The uptake of $\mathrm{Si}(\mathrm{OH})_{4}$ (mean rates 325 to $1370 \mu \mathrm{mol}$
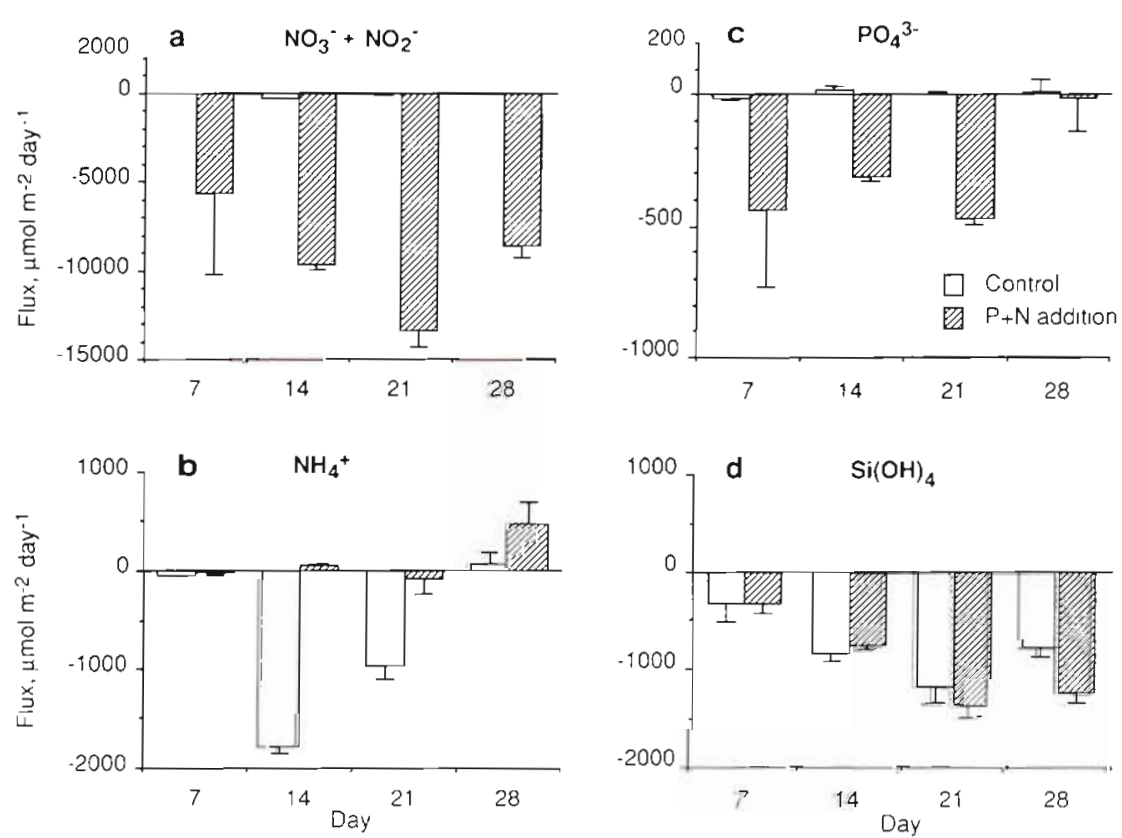

Fig. 11 Rates of decrease and increase of (a) $\mathrm{NO}_{3}^{-}+\mathrm{NO}_{2}^{-}$, (b) $\mathrm{NH}_{4}^{+}$, (c) $\mathrm{PO}_{4}^{3-}$ and (d) $\mathrm{Si}(\mathrm{OH})_{4}$ in the overlying water Each bar shows mean of 4 replicate containers + SE. For explanation of treatments see Fig. 1 
$\mathrm{m}^{-2} \mathrm{~d}^{-1}$ ) differed significantly between days and treatments (ANOVA, $p<0.01$ ) with higher uptake in enriched containers when the whole experiment is considered (Fig. 11d).

\section{DISCUSSION}

\section{Experimental set-up}

We have previously discussed the advantages and disadvantages of our experimental set-up (Sundbäck et al. 1990). The advantages include replication and adequate control treatments of communities which mimic fairly well natural communities reported from the same types of substrates. The main disadvantages are that immigration and emigration of organisms are prevented and that there is a reduced rate of water exchange and wave impact. However, for the virtually non-tidal coast of Sweden our set-up is less artificial than it would be for tidal flats characterized by regular flushing and mixing of the environment during tidal cycles. The influence of the initial exclusion of the macrofauna is further discussed in the section on nutrient fluxes.

\section{Nutrient limitation of microphytobenthos}

The raised level of inorganic $\mathrm{N}$ and $\mathrm{P}$ in the overlying water stimulated the growth of benthic microalgae, showing (a) that the microphytobenthic growth was nutrient-limited in the containers with ambient nutrient concentrations and (b) that the sediment-associated microalgae were able to assimilate nutrients from the overlying water and that they were able to, at least initially, compete with fast-growing filamentous green algae (our system did not contain phytoplankton). Several investigations from different benthic habitats have demonstrated nutrient limitation of benthic microalgae (Asmus 1986, Andersen \& Kristensen 1988, Carlton \& Wetzel 1988, Kelderman et al. 1988, Sundbäck \& Granéli 1988, Hansson 1989, Keizer et al. 1989). Our experiment suggests that the nutrient pool in the surface layer of the sediment either did not suffice or was not fully available for the microalgae. It is reasonable to expect that nutrients may rapidly be depleted in the thin photic layer (often less than $1 \mathrm{~mm}$ thick), where the primary production takes place, as demonstrated by the high-resolution oxygen microelectrode-technique (Revsbech \& Jörgensen 1983). The concentration of inorganic nutrients at the sediment/water interface is in fact often lower than in the water above and the interstitial water below (Simon 1988 and references therein). Thus the diffusion of nutrients into the pro- ducing layer becomes the rate-limiting process, and thus the primary productivity becomes dependant on water movement, which acts to decrease the thickness of the diffusive boundary layer. It is therefore reasonable to suspect that the nutrient limitation is likely to occur even more frequently in non-tidal habitats characterized by more stagnant conditions than tidal flats. De Jong \& Admiraal (1984) showed that even carbon may be a limiting factor in dense microalgal layers on tidal flats. The benthic microalgae thus depend on the nutrient pool of the overlying water and may compete with phytoplankton in shallow waters (de Vries \& Hopstaken 1984, Cariton \& Wetzel 1988).

Our scope was not to specify the most limiting nutrient for the algae in the sediment, but we simply simulated a $\mathrm{N}$ and $\mathrm{P}$ level typical for Swedish coastal areas receiving river or sewage effluents. By adding $\mathrm{NO}_{3}$ we created a situation where the so called new production', i.e. production based on $\mathrm{NO}_{3}$ as opposed to old production which is based on recirculated $\mathrm{N}$ in the form of $\mathrm{NH}_{4}$ and urea, was stimulated. Different size groups or species may favour different $\mathrm{N}$-sources as is shown for phytoplankton (e.g. Sahlsten et al. 1988). In our experiment mainly $\mathrm{NH}_{4}$ seemed to have been used in the control containers. A correlation exists between concentration and uptake (e.g. Asmus 1986), and consequently $\mathrm{NO}_{3}$ disappeared in the enriched containers, whereas some $\mathrm{NH}_{4}$ was released (perhaps partly through dissimilatory ammonium production). Conversely, excessive release of both $\mathrm{NH}_{4}$ and $\mathrm{PO}_{4}$ (Enoksson 1987, Kelderman et al. 1988, Sundbäck \& Graneli 1988) are usually coupled with low oxygen values, which at least in the overlying water did not occur in our experiment. Although the redox potential discontinuity layer probably migrated upwards during night, we could never find any signs of anoxic conditions at the sediment surface.

\section{Effect of nutrient addition on composition of the benthic autotrophs}

The stimulated growth of the green alga Enteromorpha clathrata upon $\mathrm{N}+\mathrm{P}$ enrichment agrees with previous observations that a proceeding eutrophication favours opportunistic algae such as fast-growing filamentous species (Wallentinus 1984, Lundälv et al. 1986). Both filamentous cyanophytes and small-sized diatoms gained from the changed nutrient situation and therefore a clear shift in the dominance of the major algal groups in the microphytobenthos was not observed (see Sundbäck \& Snoeijs in press). Carrick \& Lowe (1988) studied the response of benthic microalgae to enrichment with $\mathrm{Si}, \mathrm{N}$ and $\mathrm{P}$ in Lake Michigan. They found that $N+P$ enrichment induced secondary $\mathrm{Si}$ 
limitation, which favoured other algae rather than diatoms, such as cyanophytes and chlorophytes (cf. Tilman et al. 1986). The increased biomass of diatoms in our experiment indicated that at least some of the $\mathrm{Si}$ requirements were supplied, most probably from the sediment itself, since the measured uptake from the water could not cover the calculated theoretical Si requirements. Sundbäck \& Snoeijs (in press), who studied in detail the development of the diatom community, observed that small Nitzschia and Amphora species were favoured by the $\mathrm{P}+\mathrm{N}$ addition.

\section{Primary productivity and oxygen production}

The high photosynthetic activity of the sediment in the enriched containers in combination with calm conditions had a negative feedback on the producing layer from which flakes were lifted off by oxygen bubbles entrapped in the mucus-rich top sediment layer. This process may remove the producing layer in the sediment and thereby reduce the potential for autochthonous primary productivity, which is a possible explanation to the decreased autotrophic biomass seen in the enriched containers on Day 28. However it may also function as a coupling mechanism between sediment and water in shallow areas. Since sediment contains resting spores of pelagic algal species, e.g. dinoflagellates, as well as tychoplanktonic diatom species (primarily benthic species often found resuspended into the plankton), phytoplankton blooms could locally be induced in this way. An interesting question is also if the flake formation can be one of the mechanisms behind the production of the amorphous aggregates containing high densities of both autotrophic and heterotrophic organisms that have been observed during recent years e.g. in the Adriatic sea (Degobbis 1989). These aggregates often contain species typical of the benthos, such as nematodes and the semibenthic diatoms such as Nitzschia (Cylindrotheca) closterium (Fanuko et al. 1989).

\section{Bacteria}

In our experiment both bacterial biomass and production were within the lower range of values previously reported for marine sandy sediments (Kemp 1990). This was expected since there is often a positive correlation between bacterial production, organic content in the sediment and bacterial biomass, all of which are low in a sandy sediment like the one in our study. There was no good correlation between bacterial production and biomass, which agrees with the results of van Duyl \& Kop (1990).
We had expected to find a stimulated bacterial productivity in the nutrient-enriched containers as compared with control containers, since both inorganic nutrient status and primary productivity (and presumably organic exudate production too) were much higher in $\mathrm{P}+\mathrm{N}$ enriched containers. We found no such significant difference between treatments, but on the other hand the use of thymidine as a tool for measuring bacterial production has been questioned (Pedrós-Alió \& Newell 1989). Apart from possible methodological inadequacies such as our long incubation time and our lack of knowledge of the actual extraction efficiency in this sediment, there are at least 3 possible sources of error in our productivity estimates: (1) the difference between net bacterial productivity and gross bacterial productivity, (2) the dilution of isotopes, and (3) the possibility that only a fraction of cells are metabolically active. What we measure with the thymidine incorporation method is gross bacterial production (GBP), i.e. the total production of new bacterial biomass. The net bacterial production (NBP) is the net increase of biomass of the bacterial populations. The relation between GBP and NBP in our investigation depends partly on the absorption efficiency of thymidine in the guts of the grazers. In the ideal case, where all thymidine is absorbed in the meiofauna gut and where no label is respired by the meiofauna, the NBP is simply the GBP minus the amount that is grazed. With a lower absorption efficiency of label, the grazing estimates are under-estimations, and consequently the discrepancy between GBP and NBP is greater. When NBP is calculated, it is evident that less production is left for bacterial biomass increase, and on some occasions NBP is even negative (Table 1). We have no data for protozoan grazing, and since it is suggested that they are important bacterial grazers in sandy sediments (Kemp 1990), our estimation of net bacterial production is probably an over-estimation. In our study, the degree of participation of the [methyl ${ }^{3} \mathrm{H}$ ] thymidine was only ca $30 \%$, which suggests that isotope dilution is an important factor to measure in sediments, as was also found by

Table 1. Comparison between Gross Bacterial Production (GBP) and Net Bacterial Production (NBP), where NBP= GBP - the amount grazed by the meiofauna

\begin{tabular}{|c|c|c|c|c|}
\hline Day & $\begin{array}{l}\text { GBP (mg } \\
\text { Control }\end{array}$ & $\begin{array}{l}\left(\mathrm{m}^{-2} \mathrm{~d}^{-1}\right) \\
\mathrm{P}+\mathrm{N} \text { added }\end{array}$ & $\begin{array}{l}\text { NBP (mg } \\
\text { Control }\end{array}$ & $\begin{array}{l}\left(\mathrm{m}^{-2} \mathrm{~d}^{-1}\right) \\
\mathrm{P}+\mathrm{N} \text { added }\end{array}$ \\
\hline 1 & 5.8 & 10.1 & -33 & 6.5 \\
\hline 7 & 16.0 & 20.4 & 12.8 & 15.5 \\
\hline 14 & 11.8 & 12.4 & 9.4 & 7.0 \\
\hline 21 & 7.7 & 11.2 & -0.02 & -14.1 \\
\hline 28 & 25.5 & 28.6 & 23.7 & 27.9 \\
\hline
\end{tabular}


van Duyl \& Kop (1990). Our dilution estimation is based on a regression line with a coefficient of correlation of only 0.402 , and therefore the high value of dilution must be interpreted with caution. Not all bacterial cells incorporate thymidine, but the fraction of thymidineincorporating cells is often only about $20 \%$ (PedrósAlió \& Newell 1989). Of the remaining $80 \%$, not all cells are actively growing (a large proportion may be dormant), and therefore the actual production cannot be expected to be as much as 5 times the value measured by the thymidine method. Still, autoradiographic studies (e.g. Pedrós-Alió \& Newell 1989) suggest that the thymidine incorporation method is likely to underestimate the actual bacterial production.

On average, the primary productivity was 12 times the bacterial productivity in control containers, and 24 times the bacterial productivity in nutrient-enriched containers. If $10 \%$ of the primary production is lost from the algae as exudates (Hall \& Fisher 1985, Jones \& Cannon 1986), then this carbon source alone may be sufficient to sustain the bacterial growth in both treatments. As there was no significant difference in bacterial productivity between treatments, bacterial populations were apparently not limited by the total availability of carbon, nitrogen or phosphorous.

\section{Meiofauna and grazing pressure}

At the start of the experiment the biomass values of meiofauna were low compared with what has normally been found in shallow sandy habitats (Table 5 in Rudnick et al. 1985); however, the rapid growth in both treatments resulted in final densities which are typical (control containers) or high (enriched containers) for sandy sediment. In the absence of high densities of macrofaunal predators, we interpret the differences in meiofaunal densities between treatments as if meiofauna really benefited from the nutrient addition. Judging from the biomass of food organisms, meiofauna cannot have been limited by the total amount of available carbon, since algal populations remained constant (control containers) or increased (nutrient containers) during the experiment. As the meiofauna grazed only a small portion of the primary production in both treatments, food should be in. abundance. A possible cause for the apparent food limitation in control containers is that only a fraction of the algal biomass is suitable or available to the meiofauna; for example, many organisms are firmly attached to sediment particles. Admiraal et al. (1984) concluded that one of the selection mechanisms on successional patterns of benthic diatoms on tidal flats was grazing by herbivorous meiofauna. In addition to grazing by meiofauna, grazing by protozoa must be added. If protozoan grazing rates are of the same magnitude as those of meiofauna, then competition for food would occur between meiofauna and protozoa, at least for bacterial food. Meiofaunal grazing on bacteria was often a substantial part of, or even exceeded, the gross bacterial production (GBP) (Table 1) and adding protozoan grazing and natural mortality to this means that little production was available for an increase in bacterial populations. However, even if protozoan grazing and other mortality causes would increase the mortality of autotrophs to 3 times the rate of meiofaunal grazing on autotrophs, 67 or $75 \%$ of the primary production for the control and enriched containers, respectively, would be left for autotrophic growth.

Given the uncertainties in the methods of grazing estimates, how can we check if our estimations are close to reality? One crude way is to test if our estimations are sufficient to support the growth of meiofauna. If we assume a constant weight-specific grazing rate between sampling dates, and a $40 \%$ growth efficiency of meiofauna (Calow 1977), then the total amount of biomass of bacteria and algae grazed can be converted to meiofaunal biomass. While the simulation (Fig. 12) shows that the measured grazing rates are not sufficient for the meiofaunal growth, it also shows that we are within the right order of magnitude. The largest discrepancy between measured and modelled biomass was found on the last date in enriched containers. This date was characterized by low grazing rates on bacteria and a decline in autotrophic biomass, both of

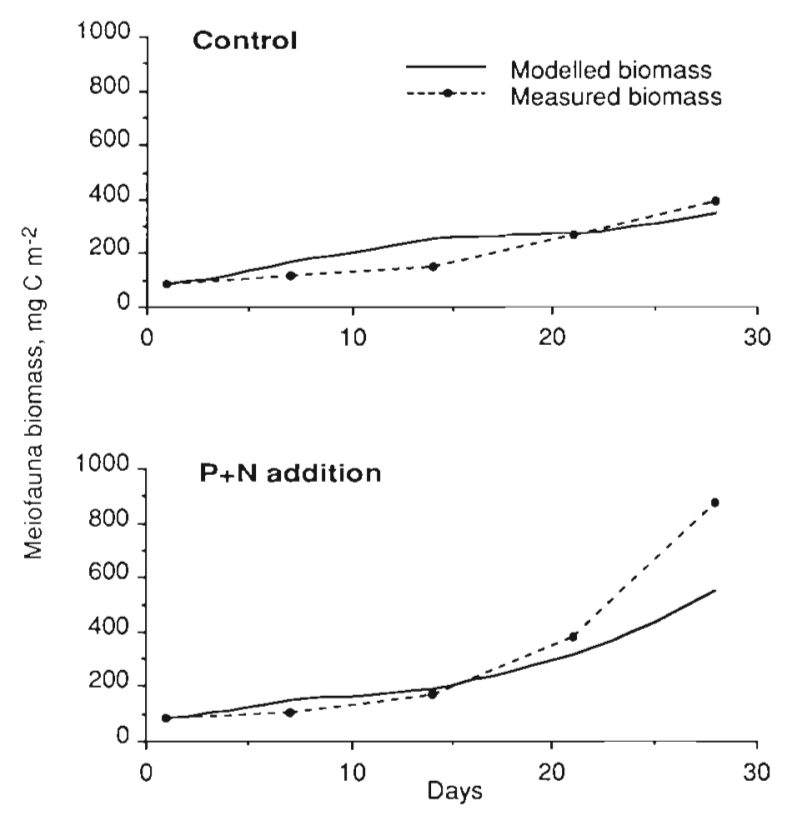

Fig. 12. Comparison between meiofaunal biomass measured by counting organisms (measured biomass) and modelled from the measured grazing rates (modelled biomass). For explanation of treatments see Fig. 1 
which influence the outcome of modelled biomass. One possible cause for the discrepancy is that we really do under-estimate grazing, either because of methodological difficulties (label is disappearing from fixed animals or inhibition values are over-estimated), or because the fundamental assumptions of the method are inappropriate (non-homogenous labelling of food organisms, extensive recirculation of tracer). An alternative is that our estimations really are close to the actual grazing rate on bacteria and algae, and the meiofauna acquire a substantial part of their nutrition from additional sources such as heterotrophic protists and non-living organic material. Both of these possibilities are probably true, and their relative magnitude (and thereby also the appropriateness of the grazing model) can only be defined by further and more specific tests.

Finally one can compare the total productivity of bacteria and autotrophs with the total grazing. By multiplying the measured primary productivity by the number of days (28), we get ca $4 \mathrm{~g}$ autotrophic carbon produced per $\mathrm{m}^{2}$ in control containers and $\mathrm{ca} 10 \mathrm{~g} \mathrm{C}$ $\mathrm{m}^{-2}$ in nutrient containers. The bacterial gross productivity during the same period amounts to 315 and 407 $\mathrm{mg} \mathrm{C} \mathrm{m}{ }^{-2}$, respectively. Comparing these values with the total biomass grazed, we find that about $8 \%$ of the primary productivity in control containers is grazed, and $4.6 \%$ in the $\mathrm{P}+\mathrm{N}$ enriched containers. It seems as if the meiofauna has a small impact on microautotrophs. A much larger fraction of bacterial productivity is grazed. High grazing rates coupled with low bacterial productivity results in $50 \%$ of the gross bacterial productivity being grazed in control containers and 90 $\%$ in enriched containers.

\section{Carbon pool of the sediment}

Of the initial POC pool, living organisms only accounted for $2.3 \%$. Although this is about $1 / 4$ of the proportion found in a previous experiment where sandy sediment from the same locality was used (Sundbäck et al. 1990\}, it does lie within the range reported by, for example, Cammen (1982). Even though ciliates and heterotrophic flagellates were not enumerated in our experiment, they probably contributed little to the total biomass. In the previous study on the same sediment ciliates accounted for 1 to $5 \%$ of the total biomass of organisms $<500 \mu \mathrm{m}$ (excl. heterotrophic flagellates that were not enumerated) (Sundbäck et al. 1990). Bak \& Niewland (1989) found that heterotrophic protozoans $<20 \mu \mathrm{m}$ contributed very little to the benthos of a Wadden Sea (Netherlands) tidal flat. In the end of our experiment, the proportion of living biomass in the organic carbon pool had increased to $4.3 \%$ and $7.6 \%$ of the POC in the control and enriched containers, respectively. Most of this increase was due to the growth of meiofauna. Although the biomass of living organisms increased significantly more with nutrient addition, a significant difference between treatments was not found in the total POC content. One explanation for this may be that the large amount of refractory material in the POC pool (cf. van Duyl \& Kop 1990) masks the minor changes coupled to changes in the biomass of sediment organisms.

\section{Nutrient fluxes}

The sediment is often considered to be an important source of nutrients for pelagial production (e.g. Flint \& Kamykowski 1984); however, shallow-water sediments have also been observed to function as sinks for nutrients (Asmus 1986, Matsukawa \& Sasaki 1986, Simon 1988, Keizer et al. 1989). In our experiment the fluxes of inorganic $\mathrm{P}, \mathrm{N}$ and Si were mostly directed into the sediment: 20 to $50 \%$ of the inorganic nutrient input to the overlying water in enriched containers disappeared during the $4 \mathrm{wk}$ experiment. The sediment alone did not account for all of the uptake, but part was taken up by the filamentous green algae. It must also be kept in mind that our results reflect a season with favourable light and temperature conditions for microphytobenthic activity in temperate areas.

When dealing with natural sediment it is difficult to find out with certainty which processes are responsible for the turnover of inorganic nutrients, unless specific tracers such as ${ }^{15} \mathrm{~N}$ and ${ }^{32} \mathrm{P}$ are used. Thus the discussion has to rely on indirect evidence gained from theoretical assumptions based on knowledge of the C:Si:N:P ratios of benthic microalgae. Bacterial turnover of $\mathrm{N}$ (nitrification/denitrification and dissimilatory $\mathrm{NH}_{4}$-production) complicates the discussion concerning nitrogen (Enoksson \& Samuelsson 1987) while $\mathrm{PO}_{4}^{3-}$ uptake is also influenced both by bacterial processes and adsorption to sediment particles in aerobic conditions (Carlton \& Wetzel 1988, Raaphorst et al. 1988). In our experiment there was an additional demand for nutrients by filamentous green algae in the enriched containers. The role of the benthic microflora in the exchange mechanisms at the sediment/water interface has been referred to as a filter-effect that regulates the flux of nutrients (and oxygen) between sediment and water (Henriksen et al. 1980, Andersen \& Kristensen 1988) via nutrient assimilation and by creating an oxidized microlayer. Consequently, a direct relationship between the primary production rate and nutrient sediment-water exchange rates has been observed (Andersen \& Kristensen 1988, Kelderman et al. 1988, Sundbäck \& Granéli 1988), thus leading to diel fluctua- 
tions in the flux rates of nutrients (Carlton \& Wetzel 1988 and references therein).

If we calculate the $N$-requirements from microalgal primary production during the entire experiment $(4044$ and $9940 \mathrm{mg} \mathrm{C} \mathrm{m}{ }^{-2}$ in control and enriched containers, respectively) by assuming a $\mathrm{C} / \mathrm{N}$ ratio of 10 (Whitaker \& Richardson 1980), we find that in the control containers where the microalgal production was nutrientlimited, the disappearance of IN would theoretically only be sufficient for up to $64 \%$ of the requirements. Obviously, the sediment pool could not fill this deficiency (cf. Keizer et al. 1989). In the enriched containers, the disappearance of IN was an order of magnitude higher than in the control containers and exceeded by about $70 \%$ the theoretical requirements of benthic microalgal requirements, thus suggesting that the rest was taken up by Enteropmorpha. Denitrification probably accounted for only a minor part of $\mathrm{N}$-disappearance in this shallow-water sandy sediment with a high oxygen production. McLachlan \& McGwynne (1986) found that only 5 to $10 \%$ of $\mathrm{N}$-input is likely to be lost by denitrification on a sandy beach (see also Seitzinger \& Nixon 1985)

The C/Si weight ratios reported for benthic diatoms vary from 1.26 (Marker \& Casey 1982) to 3.3 (Brzezinski 1985). The mean proportion of diatom biomass was 43 and $38 \%$ for the control and enriched containers, respectively. If we use the $\mathrm{C} / \mathrm{Si}$ ratio of 1.26 , the mean Si demand of diatoms would have been in the range 1.8 to $3.8 \mathrm{mmol} \mathrm{m} \mathrm{m}^{-2} \mathrm{~d}^{-1}$, and the measured uptake would then be ca 20 to $40 \%$ of these values. If the C/Si ratio of 3.3 is used, the measured uptake would account for 50 to $90 \%$ of the theoretical Si demand. However, both calculations suggest an additional Si source (the pore water) or Si limitation of the algae (cf. Kelderman et al. 1988).

There are hardly any studies on nutrient flux for shallow-water sandy sediment in non-tidal areas and therefore our results must be compared with those from sandy tidal flats. Among the 3 types of tidal flats studied by Asmus (1986), the sediment in our experimental systems can best be compared with the NereisCorophium flat, on which the benthic microalgae were the main primary producers and the macrofaunal biomass was low (Asmus \& Asmus 1985). On this flat, the flux of $\mathrm{NO}_{3}$ and $\mathrm{NH}_{4}$ during August-September were directed into the sediment and were within the same range as the flux rates in our control containers, but differed from our system in that $\mathrm{Si}$ was released (but taken up on a nearby Arenicola-flat). Our values also agree fairly well with the fluxes calculated for shallow sandy sediment in the Potomac River Estuary (Simon 1988). However, such comparisons must be done with caution, since flux are correlated with nutrient concentrations in the water and furthermore, our sediment was not influenced by tidal currents. The uptake rates of IN in a previous batch-experiment with sediment from an $\mathrm{N}$-loaded (and thus P-limited) non-tidal bay on SW coast of Sweden was 1.9 to $2.5 \mathrm{mmol} \mathrm{m} \mathrm{m}^{-2} \mathrm{~d}^{-1}$, (recalculated from Granéli \& Sundbäck 1985), i.e. 3 to 5 times less than in our enriched containers, while mean IP-uptake in the same bay (mean $25 \mu \mathrm{mol} \mathrm{m} \mathrm{m}^{-2} \mathrm{~d}^{-1}$ ) was in the lower range of that found in the enriched system.

The importance of macrofaunal excretion and bioturbation for the nutrient exchange, and in particular for the processes of $\mathrm{N}$-tumover, is well documented (e.g. Enoksson \& Samuelsson 1987, Kristensen \& Blackburn 1987, Regnault et al. 1988). On purpose, we excluded the macrofauna from our experiment to avoid the effect of bioturbation which could mask the correlation between the microbiota and nutrient flux. The populations of macrofauna in our sampling site was rather poor, comprising mainly juvenile individuals of the bivalve Cerastoderma (Cardium) edule. The release of inorganic nutrients by filter feeders has been found to stimulate primary production in sandy sediment (Lindstrom Swanberg in press). On the other hand, Andersen \& Kristensen (1988) concluded that in shallow coastal areas the influence of macrofauna in benthic metabolism appears relatively smaller than in aphotic sediments because the 'filter' effect of the benthic microalgae provides a short-cut in the nitrogen cycle, thereby counteracting the export functions of the fauna. Thus the exclusion of the natural macrofauna need not imply a serious artifact in our set-up.

\section{Food webs}

In our study the oligochaetes and harpacticoids increased more than the nematodes did. Both harpacticoids and oligochaetes are often found to be the part of meiofauna that is most readily eaten by macroscopic epifauna, such as juvenile flat fish and crustaceans (Pihl 1985, Giere \& Pfannkuche 1982). This implies that at least during the initial phase of an eutrophication process, the macrofauna is favoured in 2 ways: not only does the total amount of meiofauna increase, but the most edible fraction of the meiofauna increases the most. This may also mean that a larger portion of the meiofauna may be eaten by macrofauna. The initial phase of eutrophication may also be beneficial to herbivorous macrofauna: filter-feeders take advantage of increased food levels in the water-column and surface deposit-feeders take advantage of the stimulated growth of benthic autotrophs. In a long-time (2.4 yr) experiment Widbom \& Elmgren (1988) found that nematodes and polychaetes were positively affected by eutrophication, while harpacticoids responded negatively. One possible cause for the importance of 
oligochaetes and harpacticoids in our study may be the time-scale: both oligochaetes and harpacticoids have the potential for a very rapid population growth (Giere \& Pfannkuche 1982, Hicks \& Coull 1983) and a population response may be seen within $4 \mathrm{wk}$. Other taxa with a slower population growth e.g. polychaetes can be expected to increase in importance at a longer timescale. An other explanation may be the absence of macrofaunal predators in our study. The release of predation pressure on oligochaetes and harpacticoids may have permitted an increase in population biomass which is seldom 'allowed' in the field. It is an intriguing thought that the rapid increase in the production of oligochaetes and harpacticoids as a response to nutrient enrichment may be a common event in the field, but that this seldom is noticed because intensive predation by macrofauna prevents the build-up of high population densities.

If we use the ratio primary production/bacterial production to investigate to what extent a community is autotrophic or heterotrophic, then it appears from Figs. 1 \& 5 that the addition of $N+P$ shifted the sediment community towards a more autotrophic system.

A drastic effect of nutrient addition was the growth of Enteromorpha tufts. Enteromorpha was absent from control containers, but in enriched containers its biomass was $2.2 \mathrm{~g} \mathrm{C} \mathrm{m}^{-2}$ on Day 28 , which is almost 3 times the maximum value of microalgae we recorded. Assuming a productivity of $8 \mathrm{mg} \mathrm{C} \mathrm{g} \mathrm{DW}^{-1} \mathrm{~h}^{-1}$ (Fitzgerald 1978 cited in Wallentinus 1979) we calculated the primary production of E. clathrata to be in the order of $6 \mathrm{~g} \mathrm{C} \mathrm{m}^{-2}$ for the entire experimental period. This is more than the microphytobenthic production in control containers, but only $60 \%$ of the microphytobenthic production in enriched containers. A potentially even greater effect of Enteromorpha growth is that a continued growth may change the character of the entire habitat, converting it from a bare sandy sediment to a phytal habitat. This would lead to invasion of a flora and fauna associated to macroalgae. Moreover it would impede microphytobenthic production through nutrient depletion and shading, and possibly increase bacterial production through an increased deposition of detritus (but see Sundbäck et al. 1990). All of this would shift the sediment to a more heterotrophically dominated system.

\section{CONCLUSIONS}

(1) The increased biomass and productivity of microphytobenthos showed that the autotrophs of the sediment system were nutrient-limited. (2) A sustained high photosynthetic activity in the surface sediment, in particular in combination with stagnant conditions, may lead to flake formation, thus removing the productive top layer. (3) The rapid growth of filamentous green algae as a consequence of an increased nutrient level may eventually lead to the replacement of bare sandy areas by a more macroalgae-dominated substrate. (4) During periods of high primary productivity, shallow-water sandy sediment functions as a sink rather than a source of inorganic nutrients. (5) We could not detect any response of either the biomass or the productivity of sediment-living bacteria to inorganic nutrient enrichment. (6) The biomass of meiofauna was stimulated by nutrient enrichment, probably due to an increase of suitable or available food resources. (7) Although autotrophic organisms were more important carbon sources than bacteria for meiofauna, the impact of grazing on microautotrophic biomass was small. However, meiofaunal grazing may be very important in regulating bacterial growth. (8) In terms of biomass, the addition of nutrients led to a dominance of meiofauna, however in terms of productivity, the autotrophs predominated. Thus during the initial phase of increasing nutrient levels the entire sediment system is dominated by autotrophic processes. (9) It is important to note that our conclusions are drawn from an experiment where both planktonic organisms and macrofauna were excluded. If these groups are present, the patterns of production, grazing and nutrient exchange may be different.

Acknowledgements. Tjärnö Marine Biological Laboratory, Strömstad, and Dept of Marine Botany, University of Göteborg, provided excellent working facilities. Financial support was provided by National Swedish Environmental Protection Agency and Swedish Natural Science Research Council. We thank Birgitta Larsson for assistance in processing meiofauna samples. Dr Patricia Conway (Dept of Marine Microbiology, Goteborg) checked the English.

\section{LITERATURE CITED}

Admiraal, W., Bouwman, L. A., Hoekstra, L., Romeyn, K (1984). Qualitative and quantitative interactions between microphytobenthos and herbivorous meiofauna on a brackish intertidal mudflat. Int. Revue ges. Hydrobiol. 68: 175-191

Ertebjerg Nielsen, G., Bresta, A.-M. (1984). Guidelines for the measurement of phytoplankton primary production. Baltic Mar. Biol. (BMB) Publ. NO I, 2nd edn., Marine Pollution Laboratory, CharlottenIund.

Andersen, F. Ø., Kristensen, E. (1988). The influence of macrofauna on estuarine benthic community metabolism: a microcosm study. Mar. Biol. 99: 591-603

Asmus, R. (1986). Nutrient flux in short term enclosures of intertidal sand communities. Ophelia 26: 1-18

Asmus, H., Asmus, R. (1985). The importance of grazing food chain for energy flow and production in three intertidal sand bottom communities of the northern Wadden Sea. Helgoländer Meeresunters 39: 273-301. 
Bak, R. P. M., Nieuwland, G. (1989). Seasonal fluctuations in benthic protozoan populations at different depths in marine sediments. Neth. J. Sea Res. 24 : $37-44$

Båmstedt, U. (1986). Chemical composition and energy content. In: Corner, E. D. S, OHara, S. C. M. (eds.) The biological chemistry of marine copepods. Oxford University Press, Oxford, p. 1-58

Brzezinski, M. A. (1985). The Si:C:N ratio of marine diatoms: interspecific variability and the effect of some environmental variables. J. Phycol. 21: 347-357

Calow, P. (1977). Conversion efficiencies in heterotrophic organisms. Biol. Rev. 52: 385-409

Cammen, L. M. (1982). Effect of particle size on organic content and microbial abundance within four marine sediments. Mar. Ecol. Prog. Ser. 9: 273-280

Carlberg, S. (ed.) (1972). New Baltic manual with methods for sampling and analyses of physical, chemical and biologica] parameters. ICES Coop. Res. Rept Ser. A, Vol. 29

Carlton, R. G., Wetzel, R. G. (1988). Phosphorus flux from lake sediments: effect of epipelic algal oxygen production. Limnol. Oceanogr. 33: 562-570

Carrick, H. J., Lowe, R. L. (1988). Response of Lake Michigan benthic algae to in situ enrichment with $\mathrm{Si}, \mathrm{N}$ and P. Can. J. Fish. Aquat. Sci. 45: 2711-2719

Daro, M. H. (1978). A simplified ${ }^{14} \mathrm{C}$ method for grazing measurements on natural planktonic populations. Helgoländer wiss. Meeresunters. 31: 241-248

Degobbis, D. (1989). Increased eutrophication of the northern Adriatic Sea. Mar. Pollut. Bull. 20: 452-457

Doering, P. H., Oviatt, C. A., Beatty, L. L., Banzon, V. F. Rice, R., Kelly, S. P., Sullivan, B.K., Frithsen, J. B. (1989). Structure and function in a model coastal ecosystem: silicon, the benthos and eutrophication. Mar Ecol. Prog. Ser. 52 $287-299$

Duyl, F. C. van, Kop, A. J. (1990). Seasonal patterns of bacterial production and biomass in intertidal sediments of the western Dutch Wadden Sea. Mar. Ecol. Prog. Ser. 59: $249-261$

Enoksson, V. (1987). Nitrogen flux between sediment and water and its regulatory factors in coastal areas. Ph.D. thesis, University of Göteborg

Enoksson, V., Samuelsson, M.-O. (1987). Nitrification and dissimilatory ammonium production and their effects on nitrogen flux over the sediment-water interface in bioturbated coastal sediments. Mar. Ecol. Prog. Ser. 36: 181-189

Fanuko, N., Rode, J., Draslar, K. (1989). Microflora from the Adriatic mucous aggregations. Biol. Vestn. $37: 27-34$

Fenchel, T. M., Finlay, B. J. (1983). Respiration rates in heterotrophic, freeliving Protozoa. Microb. Biol. 9: 99-122

Finlay, B. J., Uhlig, G. (1981). Calorific and carbon values of marine and freshwater protozoa. Helgoländer Meeresunters. 34: 401-412

Fitzgerald, W. J., Jr (1978). Environmental parameters influencing the growth of Enteromorpha clathrata (Roth) J.Ag. in the intertidal zone on Guam. Botanica mar. 21 $207-220$

Fleischer, S., Hamrin, S., Kindt, T., Rydberg, L. Stibe, L. (1987). Coastal eutrophication in Sweden: reducing nitrogen in land runoff. Ambio 16: 246-251

Flint, R. W., Kamykowski, D. (1984). Benthic nutrient regeneration in South Texas coastal waters. Estuar. coast. Shelf Sci. 18: 221-230

Giere, O., Pfannkuche, O. (1982). Biology and ecology of marine Oligochaeta, a review. Oceanogr. mar. Biol. A. Rev. 20: 173-308

Granéli, E., Sundbäck, K. (1985). The response of planktonic and microbenthic algal assemblages to nutrient enrich- ment in shallow coastal waters, southwest Sweden. J. exp. mar. Biol. Ecol. 85: 253-268

Granéli, E., Wallström, K., Larsson, U., Granéli, W. Elmgren, R. (1990). Nutrient limitation of primary production in the Baltic Sea area. Ambio 19: 142-151

Green, R. H. (1979). Sampling design and statistical methods for environmental biologists. John Wiley and Sons, New York

Hall, S. L., Fisher, F. M. Jr (1985). Annual productivity and extracellular release of dissolved organic compounds by the epibenthic algal community of a brackish marsh. J. Phycol. 21: 277-281

Hansson, L.-A. (1989). Structuring forces for periphytic and planktonic algal biomass development. Doctoral thesis, University of Lund

Henriksen, K. Hansen, J., Blackburn, T. H. (1980). The influence of benthic infauna on exchange rates of inorganic nitrogen between sediment and water Ophelia, Suppl. 1: 249-256

Hicks, G. F. R., Coull, B. C. (1983). The ecology of marine meiobenthic harpacticoid copepods. Oceanogr. mar. Biol. A. Rev. 21. 67-175

Jong L. de, Admiraal, W. (1984). Competition between three estuarine benthic diatom species in mixed cultures. Mar. Ecol. Prog. Ser. 18: 269-275

Jones, A. K., Cannon, R. C. (1986). The release of micro-algal photosynthate and associated bacterial uptake and heterotrophic growth. Br. phycol. J. 21: 341-358

Jönsson, $B$. (in press). A ${ }^{14} \mathrm{C}$-incubation technique for measuring microphytobenthic primary productivity in intact sediment cores. Limnol. Oceanogr.

Keizer, P. D., Hargrave, B. T., Gordon, D. C., Jr (1989). Sediment-water exchange of dissolved nutrients at an intertidal site in the upper reaches of the Bay of Fundy. Estuaries 12: 1-12

Kelderman, P., Lindeboom, H. J., Klein, J. (1988). Light dependent sediment-water exchange of dissolved reactive phosphorus and silicon in a producing microflora mat. Hydrobiologia 159: 137-147

Kemp, P. F. (1990). The fate of benthic bacterial production. Rev. aquat. Sci., 2: 109-124

Kristensen, E., Blackburn, T. H. (1987). The fate of organic carbon and nitrogen in experimental marine sediment systems: influence of bioturbation and anoxia. J. mar. Res. 45: $231-257$

Lindström Swanberg, I. (in press). The influence of the filterfeeding bivalve Cerastoderma edule L. on benthic primary producers: a laboratory study. J. exp. mar. Biol. Ecol

Lundälv, T., Larsson, C., Axelsson, L. (1986). Long-term trends in algal-dominated rocky subtidal communities on the Swedish west coast - a transitional system? Hydrobiologia 142: 81-95

MacLachlan, A., McGwynne, L. (1986). Do sandy beaches accumulate nitrogen? Mar. Ecol. Prog. Ser. 34: 191-195

Marker, A. F. H., Casey, H. (1982). The population and production dynamics of benthic algae in an artificial recirculating hard-water stream. Phil. Trans. R. Soc. (Ser. B) 298: 265-308

Matsukawa, Y. Sasaki, K. (1986). Budgets of nitrogen, phosphorus and suspended solid in an intertidal flat. Bull. Jap. Soc. scient. Fish. 52: 1791-1797

Montagna, P. A. (1984). In situ measurement of meiobenthic grazing rates on sediment bacteria and edaphic diatoms. Mar. Ecol. Prog Ser. 18: 119-130

Montagna, P. A., Bauer, J. E. (1988). Partitioning radiolabeled thymidine uptake by bacteria and meiofauna using metabolic blocks and poisons in benthic feeding studies. Mar Biol. 98: 101-110 
Moriarty, D. J. W., Pollard, P. C. (1981). DNA synthesis as a measure of bacterial productivity in seagrass sediments. Mar. Ecol. Prog. Ser. 5: 151-156

Pedrós-Alió, C., Newell, S. Y (1989). Microautoradiographic study of thymidine uptake in brackish waters around Sapelo Island, Georgia, USA. Mar. Ecol. Prog. Ser. 55: 83-94

Pihl, L. (1985). Food selection and consumption of mobile epibenthic fauna in shallow marine areas. Mar. Ecol. Prog. Ser 22: 169-179

Pihl, L. (1989). Abundance, biomass and production of juvenile flatfish in southeastern Kattegat. Neth. J. Sea Res. 24: 69-81

Pollard, P. C., Moriarty, D. J. W. (1984). Validity of the tritiated thymidine method for estimating bacterial growth rates: measurements of isotope dilution during DNA synthesis. Appl. environ. Microbiol. 48: 1076-1083

Raaphorst, W van, Ruardij, P., Brinkman, A. G. (1988). The assessment of benthic phosphorus regeneration in an estuarine ecosystem model. Neth. J. Sea Res. 22: 23-36

Regnault, M., Boucher-Rodoni, R., Boucher, G., Lasserre, P. (1988). Effects of macrofauna excretion and turbulence on inorganic nitrogenous exchanges at the water-sediment interface. Experimental approach in microcosms. Cah. Biol mar. 29: 427-444

Revsbech, N. P, Jörgensen, B. B. (1983). Photosynthesis of benthic microflora measured with high spatial resolution by the oxygen microprofile method: capabilities and limitations of the method. Limnol. Oceanogr. 28: 749-756

Rosenberg, R., Elmgren, R., Fleischer, S., Jonsson, P., Persson, G., Dahlin, H. (1990). Marine eutrophication case studies in Sweden. Ambio 19: 102-108

Rudnick, D. T., Elmgren, R., Frithsen, J. B. (1985). Meiofaunal prominence and benthic seasonality in a coastal marine ecosystem. Oecologia 67: 157-168

Sahlsten, E., Sörensson, F., Pettersson, K. (1988). Planktonic nitrogen uptake in the south-eastern Kattegat. J exp. mar. Biol. Ecol. 121: 227-246

Seitzinger, S. P., Nixon, S. W (1985). Eutrophication and the rate of denitrification and $\mathrm{N}_{2} \mathrm{O}$ production in coastal marine sediments. Limnol. Oceanogr. 30: 1322-1339

This article was submitted to the editor
Simon, N. S. (1988). Nitrogen cycling between sediment and the shallow-water column in the transition zone of the Potomac River and Estuary. I. Nitrate and ammonium fluxes. Estuar. coast. Shelf Sci. 26: 483-497

Sundbäck, K., Granéli, W. (1988). Influence of microphytobenthos on the nutrient flux between sediment and water: a laboratory study. Mar. Ecol. Prog. Ser. 43: 63-69

Sundbäck, K. Snoeijs, P. (in press). Effects of nutrient enrichment on microalgal community composition in a coastal shallow-water sediment system: an experimental study. Botanica mar.

Sundbäck, K., Jönsson, B., Nilsson, P., Lindström, I. (1990). Impact of accumulating drifting macroalgae on a shallowwater sediment system: an experimental study. Mar. Ecol. Prog. Ser. 58: 261-274

Tilman, D., Kiesling, R., Sterner, R., Kilham, S. S., Johnson, F. A. (1986). Green, bluegreen and diatom algae: taxonomic differences in competitive ability for phosphorus, silicon and nitrogen. Arch. Hydrobiol. 106: 473-485

Wallentinus, I. (1979). Environmental influences on benthic macrovegetation in the Trosa-Askö area, Northern Baltic Proper. II. The ecology of macroalgae and submersed phanerogams. Contr. Askö Lab. Univ. Stock. 25: 1-210

Wallentinus, I. (1984). Comparison of nutrient uptake rates for Baltic macroalgae with different thallus morphologies. Mar. Biol. 80: 215-225

Whitaker, T. M., Richardson, M. G. (1980). Morphology and chemical composition of a natural population of an iceassociated Antarctic diatom Navicula glaciei. J. Phycol. 16: 250-257

Wicks, R. J., Robarts, R. D. (1987). The extraction and purification of DNA labelled with [methyl- ${ }^{3} \mathrm{H}$ ] thymidine in aquatic bacterial production studies. J. Plankton Res. 9: 1159-1166

Widbom, B., Elmgren, R. (1988). Response of benthic meiofauna to nutrient enrichment of experimental marine ecosystems. Mar. Ecol. Prog. Ser. 42: 257-268

Vries, I. de, Hopstaken, C. F. (1984). Nutrient cycling and ecosystem behaviour in a salt-water lake. Neth. J. Sea Res. 18: $221-245$

Manuscript first received: October 10, 1990

Revised version accepted: February 8, 1991 